\title{
Anti-dumping Accounting Research
}

\author{
Hui ping Huang \\ Zao Zhuang College \\ Zao Zhuang, Shan dong Province, China
}

\author{
Hui min Huang \\ Bing Tuan College \\ Wu Jia Qu, Xin Jiang, China
}

\begin{abstract}
Our objective in this report is to study the antidumping accounting. The lack of Chinese antidumping accounting ,there are the following features: It did not establish an anti-dumping accounting and competitors accounting information platform; internal accounting management system of export enterprises is not perfect; there is a certain gap between our accounting standards with international accounting standards; corporate accounting from the employment service level is not high; Chinese export companies lack pricing mechanism; there is a certain gap on Chinese companies market economy status.
\end{abstract}

We propose countermeasures are: the establishment of export product accounting information platform; export enterprise internal accounting controls; the state should improve the accounting system, speed up convergence with international accounting standards; vigorously develop the anti-dumping accounting personnel; vigorously the role of industry associations.

Keywords-import and export trade; foreign companies; antidumping accounting; Anti - dumping circumvention

\section{INTRODUCTION}

It is understood that China is the country suffered the world's most frequent anti-dumping investigations. Foreign anti-dumping on Chinese products has been a serious threat to our country's exports, China's export barriers, and with the expansion of China's yearly export scale, this problem would be to serious long-term highlight the government and enterprises in China. [1]

Many Chinese export enterprises to recognize the dangers of foreign anti-dumping investigation is not in place, thus responding to anti-dumping case is also not act positively. [2] Many domestic enterprises responding to anti-dumping cases the outcome is not obvious, which also affected some export enterprises responding to anti-dumping cases enthusiasm. This was more prominent in anti-dumping cases against Chinese products in developing countries.

\section{OVERVIEW OF ANTI-DUMPING ACCOUNTING}

\section{A. Meaning of Antidumping Accounting}

In international trade, dumping refers to a price lower than the normal value of goods sold to the importing country; the main contents include the cost of dumping and price dumping. The so-called anti-dumping accounting, refers to a specific subject using accounting knowledge, anti-dumping law knowledge and knowledge of international trade, provide accounting support to anti-dumping investigations in cases of problems encountered, accounting avoidance, accounting investigations, accounting evidence, accounting appraisal and other activities . [3] China is facing increasing trade friction, trade disputes subject gradually expanded, increasingly complex trade disputes and anti-dumping situation intensified. As international common language of business accounting, accounting information which they provide plays a vital in the anti-dumping important role. In anti-dumping, whether companies can provide accounting information comparable and fair depends largely on the quality of accounting standards. Especially when you compare between different companies, accounting information only under the guidance of a relatively high-quality accounting standard can only be provided to ensure maximum decision usefulness.

From the practical point of view, the anti-dumping accounting in order to adapt to the world market economy, to anti-dumping law theory and accounting theory, accounting data as the basis of legal norms as the criterion, treatment response will be used when anti-dumping lawsuits related accounting information. From the perspective of discipline anti-dumping accounting is a department in order to adapt to the market economy, to anti-dumping law, accounting and other relevant international trade theory and application of basic knowledge, and financial constituents as one of the new cross-disciplinary.

\section{B. The Role of Anti-dumping Accounting}

1) Anti-Dumping can circumvent anti-dumping in advance to guide enterprises:Anti-dumping accounting may be performed before the importing country has not yet begun to enter the anti-dumping investigation procedures, prior implementation of regular or irregular monitoring and analysis on important parameters exports, International Business and other domestic-related exports, accounting and real-time release of anti-dumping warning information. Moreover, by analyzing the number of goods to sell, cost, price, and the growth rate of a country or region and other data, can develop a reasonable and correct sales price for export enterprises and control the export of relevant of products the number and speed to foreign markets. So that the anti-dumping suspected to contain the initial state, so as to avoid anti-dumping investigations for purposes of prosecution.

2) Antidumping accountant can provide assistance to anti-dumping proceedings:In the face of the anti-dumping investigation, the anti-dumping accounting can help provide timely and accurate accounting of all the information needed to investigate complaints country, including: the domestic like product marketing situation, relevant business information, 
cost factor related products, to product marketing situation in third countries and so on. As long as the relevant data and accounting data can effectively prove the existence of clear accounting value of the product standards of measurement, then the associated enterprises may not be forced to a "third country export price", and even win possible.

3) Anti-dumping accounting can provide the basis for China to obtain 'market economy status':Market economy country, the implementation of a market economy, the country's government recognize the market economy, to ensure that the national system is independence and neutrality in a market economy. Market economy countries, the basic features are some differences and deviations, it is a colorful range of national market-based economy commonality. At present, although there are 75 countries and regions in recognition of China's market economy status, but for our launch major national anti-dumping, such as the United States still did not recognize China's market economy status, the EU put the country regarded as between "market economic status "and" non-market economy status "of" special market economy "countries. In the EU, to meet the "market economy status" of five conditions, and there are two related accounting. In the European Union proposed the establishment of a market economy in five standard accounting requirements are: companies must set clear basic accounting books, basic accounting books have been independently audited and versatility; accounting standards must be recorded in accordance with International Accounting Standards account. Thus accounting data occupy a very important position in the company have recognized the market economy status of the decision-making.

\section{INADEQUATE OF ANTI-DUMPING ACCOUNTING}

\section{A. Anti-dumping Accounting Accounting and Competitor Information platform}

Most Chinese companies do not establish and improve the anti-dumping mechanism, the lack of ability to deal with the actual operation of the anti-dumping cases. On the current situation, Chinese enterprises generally lack the mechanisms and instruments to cope with foreign anti-dumping investigation of the case, the lack of specialized agencies to deal with anti-dumping and trained personnel.

Competitor Accounting is a modern accounting management competitors by providing cost resources, cost structure, product development, market share, business strategies and other financial and non-financial information, and in-depth analysis to help managers carry out strategic positioning, maintaining relative competitive advantage, to obtain excess returns.

\section{B. Situation of Export Internal Accounting Management System}

1) Accounting disorder:Accounting work order uncoordinated mainly in corporate accounting is not in accordance with the relevant standard operating procedures, without certificate, mixed post; non-compliance with the national relevant financial laws and regulations. There is no strict compliance with corporate financial systems related business activities for accounting, accounting supervision, despite the unit responsible for directing

2) Corporate accounting information is untrue, incomplete accounting:This is mainly reflected in the use of false invoices in the enterprise, fabricate and provide false corporate financial statements, kangaroo internal coffers, any interception or withhold relevant income, mob unjustified costs, fees, etc.. This is caused by false accounting, incomplete information accounting information distortion common serious reaction.

3) China's current accounting regulations do not support the presence of imperfect phenomenon:There are many Chinese enterprises through the manipulation of accounting information, so as to achieve tax evasion obtain illegitimate "economic interest" purposes. Specific performance is the use of accounting errors in accounting policies, changes in accounting estimates and provisions related transaction price, corporate financial information is processed in different periods, income tax evasion cases are more manipulated profits, making a false performance.

4) Accounting Professional Ethics low, any fraud:Mainly for some accountants do not make progress, the lack of research related business spirit, the spirit of the lack of ethics and professionalism in the work of subjective and arbitrary strong. They do not strictly in compliance with the accounting system to handle business transactions, and therefore very easy resulting in distortion of accounting information.

\section{China's Accounting Standards with International Accounting Standards}

Production costs to determine the anti-dumping cases is the most important one of the elements, it directly affects the calculation of the normal value of the product. The corporate accounting standards and have a direct impact on the cost calculation, the cost of using different accounting standards also out of the same product may vary. So in most countries, anti-dumping laws are made directly to the relevant export enterprises Accounting Standards Provisions. Chinese accounting standards and international practice, there are still some gaps, differences related products costing method will directly affect product pricing and tariffs, etc..This leading to import the relevant state agencies to investigate the accounting information and product cost of Chinese enterprises is not to be recognized, and switch to substitute another third country as comparable price data, which leads to all efforts were in vain before.

\section{Enterprise Accounting from Employment Status of Business Standards}

Since the anti-dumping accounting particularity and complexity compared with other accounting, in addition to the anti-dumping accounting practitioners should have the quality from the general accounting personnels, it should also be familiar with international accounting standards, familiar with 
international trade knowledge, with skilled Language communication. The majority of our employees do not understand the accounting international anti-dumping law, do not have much knowledge of international trade, foreign language proficiency is also generally not high.

\section{E. ChineseExportEnterprises Product Pricing Mechanism}

The level of sales price in the first anti-dumping factors need to be considered. Sales of product pricing, accounting should participate. In order to avoid anti-dumping investigations abroad, the company's export price should not be less than their selling prices in the domestic market. [4] Otherwise, it may lead to suspicion of foreign enterprises, and thus lead to anti-dumping investigations. Because China's low labor costs, so some labor-intensive products in the international market price is relatively low. It would have the advantage of Chinese enterprises. But because the Chinese export enterprises generally do not attach importance to accounting guidance on export policy, do not attach importance to understand market conditions of similar foreign products, which export products market pricing often without reference accounting advice and guidance personnel. This resulting in price competition in the blind, the result is the whole of China's foreign trade enterprises compromised.

\section{F. on Chinese Companies Market EconomyStatus}

European countries in accordance with recognized standards of market economy, if they want to gain market economy status they must do two things: the enterprise have a clear basis of accounting books, the books need to develop in accordance with international accounting standards, and has been Independent Auditing versatility; enterprise financial condition and production costs are no longer a conventional non-market economy status and distorted. [5] only two conditions in this regard, the majority of our business there is a big gap.

\section{ACCOUNTING STRATEgIES OF ANTI-DUMPING CASES}

\section{A. ExportsAccounting Iinformation Platform}

1) Establish Chinese exports anti-dumping accounting information application platform:Profile of a comprehensive anti-dumping information platform is responding to foreign anti-dumping investigation cases of necessity. [6] Exporters Anti-dumping information database includes the establishment of a competitor accounting database and the establishment of anti-dumping accounting repository in two ways. Accounting information on competitors can provide not only the importing country the same or similar products of competitors in third countries Basic Information on competitors, but also market share, business strategy, product development and other nonfinancial information.

2) Establish and improve accounting information platform to circumvent anti-dumping:To reduce foreign companies on Chinese exports lifted effective method dumping prosecution investigation by China's exports and export products in the international market situation and other data analysis, monitoring, in order to develop a more reasonable exit strategy, and regularly publish anti-dumping investigations warning information. This requires that the relevant export industries establish circumvention of antidumping accounting information platform. Through the important parameters of exports and other monitoring, collation and analysis through accounting logistics and other methods for key products, key industries, key regional and national market conditions on a regular basis or irregularly publish anti-dumping investigation of early warning information. In order to achieve the purpose of circumvention of anti-dumping investigations, thereby establishing the system of anti-dumping proceedings survey early warning database.

3) Perfect proof of anti-dumping information platform construction:Respond to foreign anti-dumping lawsuits, requires a lot of accounting information and the need for accounting information in different periods of accounting evidence. Therefore, the construction of a sound anti-dumping evidence of accounting information platform, is of a very prominent significance to improve the relevant enterprises in the anti-dumping due to the effectiveness of the time.

\section{B. Internal Accounting Management of Export}

1) Education accountants to establish the concept of integrity:Organization of accounting practitioners accounting ethics education, learning to comply with the relevant laws and regulations and the financial system, develop a conscious act according to law, abide by good habits. Do knowing the law in dealing with all kinds of economic activities, to ensure the provision of high-quality accounting information.

2) Improve the relevant management accounting system:Accounting related management system should do clear norms, should make every effort to narrow accounting choices, and possible future changes in accounting environment, scientific forecasting. So that the accounting management system is with advanced, stable and sustainable characteristics and build "decision usefulness approach."

3) Improve laws and regulations, increase the punishment for illegal behavior:Improve relevant laws and regulations, amendments to existing laws and regulations which are not clear some responsibility and punishment provisions, increase the laws new situation of reality. In the law inspection work related to the construction of legal supervision departments must be done strictly enforced, increase the punishment, serious financial law, increase penalties for counterfeiters. So counterfeiters are far less than the cost of its proceeds to pay in order to more effectively prevent counterfeiters any violations of financial laws and regulations related to poor behavior.

4) Foster a good economic environment:To better establish the accounting sense of integrity, we should also do our utmost to create a good atmosphere of Accounting Integrity: first within the unit we should be building a sound scientific and rational and efficient internal control system, 
which is an important method of controlling the phenomenon of Accounting Fraud. Second, we must pay attention to oversight role in guiding public opinion, the accounting officer of the advanced deeds should vigorously promote vigorously to play a guiding role model integrity. We should guide to accounting practitioners to learn, while the dishonest accountants modest exposure. Third, we must strengthen the construction of the accounting industry self-regulatory organization, which is the successful experience of management accounting.

\section{States Should Improve theAccounting System, Speed up Convergence with International Accounting Standards}

To join WTO means that companies have to align it with international standards of financial accounting, corporate management, acting in accordance with internationally accepted standards. China should strive to accepted accounting standards developed by the International Accounting Standards Board, regarding specific issues should also be carried out under the guidance of international accounting standards.

\section{Vigorously Develop the Anti-dumping Accounting Personnel}

1) The current anti-dumping accounting personnel of the situation:Although China has 12 million people accounting, but still showing the proportion of accounting personnel incoordination, no optimization of the structure. the lack of a number of complex, high-quality, international accounting personnel is still short board development of Chinese enterprises. Chinese enterprises to go international, to participate in international mergers and acquisitions, companies need to understand a number of dealings with the world and can solve the accounting personnel, such as antidumping and other international disputes.

2) How to train Anti-dumping Accounting Talents:First, The Government should increase efforts to train personnel on anti-dumping, anti-dumping and effective implementation of personnel training programs in different ways. Second, enterprises can encourage accounting staff to improve accounting practices, learning a foreign language, improve foreign language level, learning anti-dumping law knowledge and knowledge of international trade, to learn how to fill out the questionnaire, and so the anti-dumping accounting

\section{E. The Role Played by Industry Associations}

1) Introduction Industry Association:Industry associations means social intermediary organizations interposed between the government, enterprises, industry and commodity production operators, and coordination of their services, consultation, communication, supervision, fairness, selfdiscipline.

2) Role of industry associations:From the practice of States, the enterprise implementation of anti-dumping, countervailing and other legal measures in most of the complainant industry organizations, the anti-dumping case to the government agency or individual enterprises as the complainant's is very rare. This is mainly because the antidumping itself is an industry problem. Anti-dumping Complaint must dumping and the consequent damage caused to the domestic industry of sufficient appropriate evidence includes the presence. Only enterprises concerned industry associations to work together in order to complete the information provided.

\section{CONCLUSION}

As China increasingly close economic ties with the world, so in the foreseeable future, the number of foreign companies to the anti-dumping investigation cases my country will likely rise further. Accounting will play an increasingly important role in anti-dumping cases under investigation.

By studying the above accounting in response to antidumping investigations in the status ; the main problems accounting in our country, and countermeasures and other aspects of the analysis, we concluded that China must pay attention to the role of accounting in anti-dumping and improve the anti-dumping accounting system of protection. At the same time speed up the training of anti-dumping accounting personnel, in order to increase our chances of winning in response to anti-dumping, and thus effectively protect the legitimate rights and interests of China's export enterprises.

\section{REFERENCES}

[1] Jian Shen, "reasons of "Made in China" frequent anti-dumping investigation - to safeguard tire Perspective", Henan Judicial Police Vocational College, 2010 , pp.21-23.(In Chinese)

[2] Tie $\mathrm{Xu}$, “Analysis of the impact of new accounting standards for China's anti-dumping”, INTELLIGENCE (intelligence) Finance and Audit, 2010 , pp.38-40.(In Chinese)

[3] Yaru He, "On the status of the international anti-dumping, Causes and Countermeasures”, International Trade to explore, 2010, pp.31-33.(In Chinese)

[4] Jianli Fu, "character Motivation anti-dumping analysis and response ”, Chinese national conditions and strength, 2010 , pp.18-19.(In Chinese)

[5] Zheng Sun, "Hao Liu. Anti-dumping Accounting Research Issues Analysis”, Accounting Research, 2005, pp.28-29.(In Chinese)

[6] Zheng Mao, "On Chinas Legal Countermeasures to foreign antidumping ”,Law and Society, 2010 , pp.38-39.(In Chinese) 